\title{
Paregreg Dalam Sebuah Monumen
}

\section{Baskoro Daru Tjahjono}

Keywords: sima, hindu-buddha, war, majapahit, architecture

\section{How to Cite:}

Tjahjono, B. D. (1999). Paregreg Dalam Sebuah Monumen. Berkala Arkeologi, 19(2), 68-76. https:// doi.org/10.30883/jba.v19i2.823

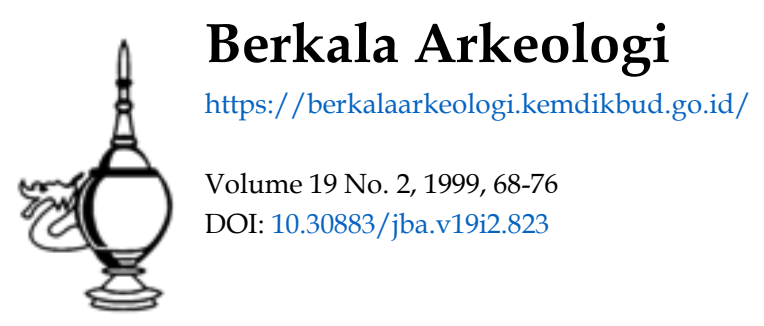

\section{c) (1) (5)}

This work is licensed under a Creative Commons Attribution-NonCommercial-ShareAlike 4.0 International License. 


\title{
PAREGREG DALAM SEBUAH MONUMEN
}

\author{
Baskoro Daru Tjahjono \\ (Balai Arkeologi Yogyakarta)
}

Peristiwa-peristiwa penting yang berkaitan dengan perjalanan sejarah suatu bangsa sering diperingati dengan pendirian sebuah monumen di tempat-tempat terjadinya peristiwa tersebut. Hal ini dilakukan untuk inengingatkan para generasi penerus akan peristiwa sejarah yang telah terjadi pada masa lalu, sehingga spirit dan nilai-nilai kejuangannya diharapkan selalu mengilhami mereka. Monumen-monumen itu bisa berupa bangunan gedung yang megah dengan diorama peristiwa sejarah atau berupa sebuah tugu yang kecil saja. Contoh-contoh monumen peringatan peristiwa-peristiwa yang berkaitan dengan kemerdekaan bangsa Indonesia dari penjajahan bangsa asing misalnya: Monumen Nasional (Monas) dan Monumen Proklamator di Jakarta, Monumen Serangan Umum 1 Maret dan Monumen Yogya Kembali di Yogyakarta, Tugu Pahlawan 10 November di Surabaya, dan masih banyak lagi. Monumenmonumen tersebut biasanya didirikan jauh setelah peristiwa-peristiwa sejarah itu berlangsung.

Pada masa lalupun, peristiwa-peristiwa penting yang terjadi masa itu sering diwujudkan dalam bentuk monumen. Misalnya pada masa kerajaan-kerajaan Hindu masih berkuasa di Indonesia, pendirian sima sering dikaitkan dengan jasa yang telah diberikan oleh masyarakat sebuah desa terhadap rajanya. Untuk memperingati peristiwa itu kemudian didirikan sebuah bangunan suci, dan masyarakat desa yang bersangkutan diwajibkan untuk memeliharanya. Karena adanya beban untuk memelihara bangunan suci maka masyarakat desa tersebut dibebaskan dari kuwajiban membayar pajak kepada raja. Sebuah bangunan yang baru saja di temukan di Dukuh Centong, Desa Sawentar, Kecamatan Kanigoro, Kabupaten Blitar kemungkinan merupakan salah satu contoh sebuah bangunan yang merupakan monumen peringatan suatu peristiwa penting pada masa Majapahit. Walaupun bangunan itu tidak terlalu besar namun sangat menarik untuk diteliti, terutama jika dikaitkan dengan latar belakang sejarahnya serta bentuk arsitekturnya yang langka. 
Peninjauan arkeologi yang telah dilakukan Balai Arkeologi Yogyakarta pada tanggal 17 sampai dengan 19 Mei 1999 telah berhasil mengidentifikasi temuan benda-benda arkeologi di Situs Sawentar. Benda-benda arkeologi yang ditemukan diantaranya Berupa fragmen sebuah miniatur candi yang diperkirakan berukuran tinggi antara 1,5 sampai 2 meter dan denahnya $1 \times 1$ meter. Miniatur candi ini bentuk dan langgamnya mirip dengan Candi Angka Tahun (1369 M) yang terdapat di kompleks Candi Panataran di utara Kota Blitar. Komponen-komponen bangunan miniatur candi yang telah ditemukan antara lain bagian-bagian atap dan bagian-bagian tubuh candi (ditemukan dua buah relung yang berupa pintu semu). Selain itu juga ditemukan tiga buah panil berrelief binatang, masing-masing berukuran $61 \times 32 \mathrm{~cm}$.

Berdasarkan angka tahun yang tertera di atas salah satu pintu semu pada bangunan miniatur candi tersebut semula diidentifikasikan angka 1257 C (1335 M). Dengan identifikasi tersebut maka benda-benda arkeologi itu diperkirakan berasal dari masa pemerintahan Tribuwana Wijayotunggadewi, yang memerintah Majapahit antara tahun 1250 - 1272 C $(1328-1350 \mathrm{M})$. Namun setelah dikonfirmasikan dengan beberapa ahli epigrafi ternyata terdapat kesalahan dalam pembacaan angka tahun tersebut sehingga mengganggu dalam interpretasinya. Menurut Richardiana Kartakusuma angka tahun tersebut seharusnya dibaca 1357 C $(1435 \mathrm{M})$. Jika pembacaan angka tahun ini benar berarti bangunan tersebut tidak berasal dari masa pemerintahan Tribuwana Wijayotunggadewi melainkan dari masa pemerintahan Suhita. Identifikasi ini sedikit berbeda dengan pembacaan Tjahjono Prasodjo, yang terbaca angka tahun 1369 Ç (1447 M). Sedangkan Djoko Dwiyanto membaca angka tahun tersebut $1358 \mathrm{C}(1436 \mathrm{M})$. Dengan demikian ada dua angka tahun yang sangat dekat, sehingga untuk sementara candi ini diinterpretasikan berasal dari tahun 1357 atau $1358 \mathrm{C}(1435 / 1436 \mathrm{M})$. Dengan demikian berarti candi ini dibangun pada masa Suhita, yang memerintah Majapahit tahun 1351-1369 C (1429-1447 M).

Setelah berhasil mengidentifikasi temuan kemudian dilanjutkan dengan peninjauan ke lokasi situs yang terletak di lingkungan pasar Desa Sawentar. Pengamatan terhadap lingkungan situs difokuskan pada singkapan tanah yang dapat diamati di lubang sumur yang merupakan fasilitas pasar tersebut. Pengamatan terhadap sumur dilakukan karena dari sekitar tempat itulah benda-benda arkeologi tersebut ditemukan. Dari pengamatan itu ditemukan adanya sisa-sisa struktur bata kuna yang masih menempel di dinding sumur. Dari hasil identifikasi maka diperkirakan bahwa di lokasi situs terdapat sebuah candi atau kompleks candi yang masih terpendam tanah akibat endapan lava sedalam lebih kurang 2 meter. Candi ini diperkirakan mirip dengan candi induk Panataran, karena mempunyai bentuk-bentuk miniatur candi yang merupakan hiasan pada teras-terasnya dan relief-relief pada dinding-dindingnya. 
Ekskavasi yang dilakukan di Situs Sawentar telah berhasil membuktikan adanya sebuah candi atau kompleks candi. Candi atau kompleks candi ini ternyata berukuran tidak terlalu besar, jadi tidak sesuai dengan dugaan semula yang diperkirakan mirip dengan bangunan induk Panataran. Ekskavasi yang dilakukan dengan teknik parit (trensch) berhasil menampakkan struktur-struktur bangunan baik dari bahan batu andesit maupun bata. Struktur-struktur bangunan ini membentuk denah-denah empat persegi panjang dan bujur sangkar yang berderet dari barat ke timur, pada bagian paling timur dibatasi oleh sebuah pagar dari bata. Pagar bata ini membujur utaraselatan dan mempunyai pilar yang besar. Struktur pagar ini baru ditemukan pada sisi timur candi bagian selatan.

Pagar ini selain sebagai batas halaman kemungkinan juga untuk mencegah banjir dari sungai kuna di sebelah timurnya. Bukti adanya usaha untuk mencegah banjir antara lain ditunjukkan dari kuatnya konstruksi pagar yang dibuat dari dua lapis bata yang dijajar sehingga tebal dinding sekitar $40 \mathrm{~cm}$. Sedangkan pilarnya juga besar berbentuk empat persegi panjang dengan tebal $70 \mathrm{~cm}$ dan panjang $100 \mathrm{~cm}$. Bagian bawah pagar tertanam di dalam tanah sedalam $30 \mathrm{~cm}$ dan di bawahnya diberi penguatan dengan tatanan bolder. Bukti bahwa bagian ini tertanam di dalam tanah tampak dari sudutsudut pilar yang masih utuh (tidak aus), sedang bagian yang tidak tertanam dalam tanah sudut-sudutnya terlihat aus, lebih-lebih pada dinding sebelah timur tampak adanya bekas-bekas gerusan air. Selain itu bagian yang tertanam dalam tanah warna batanya merah agak kehitaman, sedangkan yang tidak tertanam dalam tanah berwarna merah kekuningan. Tinggi pagar bata yang masih tegak 1 meter, kemungkinan dahulu lebih tinggi lagi, hal ini tampak dari adanya sisa-sisa runtuhan bata di sekitar dinding pagar.

Denah kompleks bangunan belum tampak secara utuh, namun beberapa bagian sudah dapat diperkirakan bentuknya. Kompleks bangunan tersebut kemungkinan dikelilingi oleh pagar halaman dari bata, di dalamnya terdapat beberapa bangunan kecil-kecil yaitu dua buah bangunan bata berbentuk bujur sangkar berjajar utara dan selatan terletak di bagian paling barat kompleks. Di sebelah timur bangunan bata terdapat bangunan batur (soubasement) yang kemudian disebut batur I, berbentuk empat persegi panjang membujur utara-selatan. Batur I ini terbuat dari batu andesit, sedangkan lantainya di bagian tengah terbuat dari bata. Di sebelah timur batur I terdapat bangunan batur II yang berbentuk empat persegi panjang juga, membujur utara-selatan, namun seluruhnya baik dinding maupun lantainya terbuat dari batu andesit. Di atas batur II ini terdapat dua bangunan berbentuk bujur sangkar di sisi utara dan sisi selatan, sehingga lantai batur tampak di antara kedua bangunan ini.

Bangunan sisi utara terdiri atas bagian kaki berprofil dengan pelipit sisi genta dan pelipit-pelipit persegi, di atasnya ditemukan dua buah panil berrelief binatang, salah 
satunya masih tegak pada tempatnya (intact). Kemungkinan panil-panil yang sudah ditemukan sebelumnya juga berasal dari bangunan ini, karena ukuran panil tersebut sama dengan dua buah panil yang baru ditemukan melalui ekskavasi ini. Namun ada sedikit permasalahan, yaitu berdasarkan ukuran panjangnya $(62 \mathrm{~cm})$ jika seluruh panil dipasang berkeliling bangunan ini hanya dapat memuat 4 buah panil, sedangkan yang sudah ditemukan sebanyak 5 buah panil. Ada satu panil yang tersisa, jika ditempatkan pada bangunan di sebelah selatannya tentunya harus ada 3 buah panil lagi.

Permasalahan yang lain adalah letak bangunan miniatur candi. Komponen-komponen miniatur candi yang telah ditemukan hingga saat ini adalah beberapa bagian komponen atap dan komponen tubuh miniatur candi. Komponen tubuh ini telah ditemukan 4 buah pintu semu. Jadi hingga saat ini telah ditemukan satu unit miniatur candi. Bentuk miniatur candi ini ternyata mirip dengan 2 buah miniatur candi yang terdapat di halaman pertama kompleks candi Panataran yang juga dilengkapi dengan relung pintu semu, kepala kala, dan angka tahun. Masalahnya komponen-komponen miniatur candi itu ditemukan tidak pada posisinya yang benar (intact), sehingga belum dapat dipastikan letaknya, namun kemungkinan terletak di atas salah satu atau kedua bangunan bujursangkar yang terdapat pada batur II.

Permasalahan lain lagi adalah adanya struktur bangunan bata berbentuk empat persegi panjang yang membujur utara-selatan. Struktur bata ini terletak di sebelah barat batur II dan di atas batur I. Posisi di atas batur I ini menjadi masalah karena tidak menempel pada batur I tetapi di bawah bata terdapat lapisan tanah setebal $20 \mathrm{~cm}$. Jadi kemungkinan struktur bata ini bukan bangunan yang sejaman dengan batur I maupun batur II. Kemungkinannya adalah di kompleks candi ini telah terjadi beberapa kali pengendapan lava Gunung Kelud. Pada pengendapan pertama telah menutup bagian batur kompleks candi, sehingga yang tampak di permukaan tanah tinggal bagian atas yang berupa miniatur candi dan bangunan berrelief. Bagian-bagian bangunan yang masih tampak ini kemudian dimanfaatkan oleh masyarakat sekitar pada masa kemudian untuk keperluan religius dengan menambah bangunan baru berupa struktur bata di sebelah barat bangunan yang masih tampak tersebut. Kemungkinan bangunan baru ini ditambahkan sebagai bangunan altar yang merupakan kelengkapan sebuah bangunan pemujaan.

Secara keseluruhan kompleks bangunan ini belum dapat diketahui fungsinya, sebab yang berhasil ditampakkan baru sebagian saja. Bangunan berbentuk miniatur candi biasanya bukan merupakan bangunan yang berdiri sendiri, melainkan merupakan bagian dari suatu bangunan yang lebih besar. Seperti pada kompleks Candi Panataran di halaman pertama terdapat dua buah miniatur. candi. Selain itu bentuk-bentuk miniatur candi juga sering terdapat pada bangunan-bangunan petirtaan, seperti Candi Tikus dan Candi Simbatan. Namun untuk Candi Saventar II yang baru ditemukan ini belum menunjukkan tanda-tanda sebagai bangunan petirtaan walaupun letaknya 
berada di dekat sungai kuna. Candi-candi yang berfungsi sebagai petirtaan biasanya mempunyai lubang-lubang kecil sebagai jalan keluarnya air, bisa berupa jaladwara, arca-arca dengan puting susu yang berlubang, atau arca-arca wanita membawa periuk (klenting/ tempat air dari tanah liat) yang berlubang. Lubang-lubang sebagai jalan keluar air ini tidak (belum) ditemukan di Candi Sawentar II.

Selain fungsi bentuk secara utuh dari bangunan ini juga belum dapat diungkap melalui ekskavasi tahap pertama ini. Ekskavasi lebih lanjut yang lebih sistematis masih diperlukan, sehingga diharapkan akan dapat menjelaskan bentuk dan fungsi bangunan tersebut.

Pendirian sebuah candi biasanya bertalian erat dengan peristiwa meninggalnya seorang raja. Hal ini dapat diketahui dari keterangan-keterangan yang termuat dalam kitab Nagarakrtagama dan kitab Pararaton (Soekmono dan Inajati, 1993: 67). Candi didirikan untuk mengabadikan "dharma"nya dan memuliakan rohnya yang telah bersatu dengan dewa penitisnya. Misalnya: Candi Jago merupakan tempat pendarmaan Raja Wisnuwardhana, Candi Singasari dan Candi Jawi untuk memuliakan Raja Kertanagara, dan Candi Simping untuk memuliakan Raja Kertarajasa. Namun selain sebagai tempat pendarmaan raja yang telah meninggal apakah tidak ada tujuan lain dalam pendirian suatu bangunan suci itu. Apakah tidak mungkin pula suatu bangunan suci didirikan untuk memperingati peristiwa-peristiwa penting yang telah terjadi dalam suatu kerajaan. Latar belakang peristiwa sejarah suatu kerajaan atau latar belakang naik tahtanya seorang raja tampaknya juga mengilhami pendirian suatu bangunan suci.

Hal ini salah satunya tampak dari pendirian bangunan suci di situs Sawentar II. Walaupun bentuk bangunan secara utuh belum dapat diketahui demikian pula fungsinya, namun dari salah satu panil dapat diperkirakan bahwa maksud pendirian bangunan ini untuk memperingati suatu peristiwa penting pada masa lalu. Salah satu panil (yang masih intact) menggambarkan seekor naga bermahkota sedang memakan Surya Majapahit. Panil itu menghadap ke barat dan terletak pada sisi barat bangunan bujur sangkar sebelah utara yang terdapat di atas batur II. Gambar tersebut kemungkinan merupakan bentuk penulisan angka tahun yang diwujudkan dalam gambar (candra sengkala). Candra sengkala atau sengkalan sering digunakan sebagai peringatan tentang kejadian atau peristiwa yang khusus, seperti berdirinya kerajaan, kenaikan tahta raja, kelahiran, peperangan, serta peristiwa lainnya (Suwatno, 1998/1999: 81). 
Jika ditulis dalam kalimat maka candra sengkala itu akan berbunyi: "Nagaraja anahut surya". Naga mempunyai nilai 8 , raja mempunyai nilai 1 , anahut mempunyai nilai 3 , dan surya mempunyai nilai 1. Jadi "Nagaraja anahut surya" berarti tahun 1318 C (1396 M). Pada tahun itu Majapahit masih diperintah oleh Wikramawarddhana ayah Suhita, yang memerintah antara tahun 1311-1351 C $(1389-1429$ M). Wikramawarddhana adalah keponakan dan menantu Hayam Wuruk (Djafar, 1978: 45). Dia naik tahta karena mengawini Kusumawarddhani, anak Hayam Wuruk dari parameswari. Dengan demikian Kusumawarddhani-lah yang sebenarnya berhak atas tahta kerajaan karena sebagai putri mahkota.

Sepeninggal raja Hayam Wuruk dan Patih Amangkubhumi Gajah Mada Majapahit telah mengalami kesuraman dan muncul suatu masalah yaitu perebutan kekuasaan dan pertentangan keluarga mengenai hak waris atas tahta kerajaan. Oleh Hayam Wuruk kerajaan dibagi dua yaitu di sebelah barat (Majapahit) diperintah oleh Wikramawardhana dan kerajaan di timur (daerah Balambangan) diperintah oleh Wirabhumi, anak Hayam Wuruk dari istri selir (Djafar, 1978: 45).

Pemahatan relief "Nagaraja anahut surya" di Candi Sawentar II kemungkinan merupakan penggambaran adanya peristiwa atau upaya perebutan tahta kerajaan di Kerajaan Majapahit. Pada masa pemerintahan Wikramawarddhana telah terjadi pertentangan keluarga, antara Wikramawarddhana yang memerintah wilayah bagian barat (Majapahit) dengan Bhre Wirabhumi yang memerintah bagian timur (daerah Balambangan). Di dalam Serat Pararaton peristiwa itu disebut paregreg, yang mulai terjadi tahun 1323 Ç (Djafar, 1978: 45-46). Tahun 1318 Ç yang tersirat dalam sengkalan "Nagaraja anahut surya" sangat dekat dengan mulai terjadinya peristiwa paregreg. Jadi kemungkinan sebelum mulai peristiwa paregreg telah didahului dengan peristiwa-peristiwa yang berkaitan dengan upaya perebutan tahta tersebut. Atau kemungkinan angka tahun itu menunjuk tahun mulainya peristiwa paregreg. Kemungkinan tahun yang disebut oleh penulis Pararaton kurang tepat, mengingat penulisan Pararaton jauh setelah peristiwa itu berlangsung (sekitar abad XVII M), sedangkan candi Sawentar II yang memuat sengkalan "Nagaraja anahut surya" berasal dari tahun 1357 atau 1358 Ç (1435/ 1436 M). Jadi candi Sawentar II didirikan 40 tahun setelah peristiwa paregreg terjadi. Jika hal ini benar berarti Candi Sawentar II didirikan oleh Suhita untuk memperingati peristiwa upaya perebutan tahta (paregreg) yang terjadi pada masa pemerintahan ayahnya.

Apabila diamati dari makna penggambaran naga yang mengenakan mahkota, sangat mungkin hal itu merupakan simbolisasi seorang raja yang marah, dan digambarkan sedang berusaha menelan matahari. Sedangkan matahari yang dicaplok naga raja tersebut merupakan simbolisasi dari kekuasaan kerajaan Majapahit yang sedang dicabik-cabik untuk diruntuhkan. Sebab matahari yang digambarkan pada panil itu adalah "Surya Majapahit" yang merupakan lambang kebesaran Kerajaan Majapahit. 
Dengan demikian penggambaran "Nagaraja anahut Surya" adalah untuk menggambarkan adanya upaya-upaya untuk meruntuhkan kekuasaan Majapahit melalui perebutan tahta oleh Wirabhumi terhadap kekuasaan Wikramawarddhana yang oleh Pararaton disebut "Paregreg". Jadi maksud pendirian bangunan suci Sawentar II adalah untuk memperingati peristiwa paregreg yang telah terjadi 40 tahun lalu sebelum bangunan itu didirikan.

\section{KEPUSTAKAAN}

Djafar, Hasan. 1978. Girindrawarddhana, Beberapa Masalah Majapahit Akhir, cetakan kedua, Jakarta: Yayasan Dana Pendidikan Nalanda.

Kempers, A.J. Bernet. 1959. Ancient Indonesian Art, Amsterdam: C.P.J. van Der Peet.

Padmapuspita, J. 1966. Pararaton, Yogyakarta: Taman Siswa.

Siswanto. 1998/1999. Studi Relief Flora dan Fauna Tinggalan Masa Majapahit Laporan Penelitian Arkeologi, Balai Arkeologi Yogyakarta.

Suwatna, Edi. 1998/1999. Perspektif Budaya Candrasengkala, Kebudayaan, Nomor 16 Tahun VIII 1998/1999, Departemen Pendidikan dan Kebudayaan.

Soekmono dan Inajati Adrisijanti Romli. 1993. Peninggalan-peninggalan Purbakala Masa Majapahit, 700 Tahun Majapahit (1293-1993) : Suatu Bunga Rampai, Surabaya. 


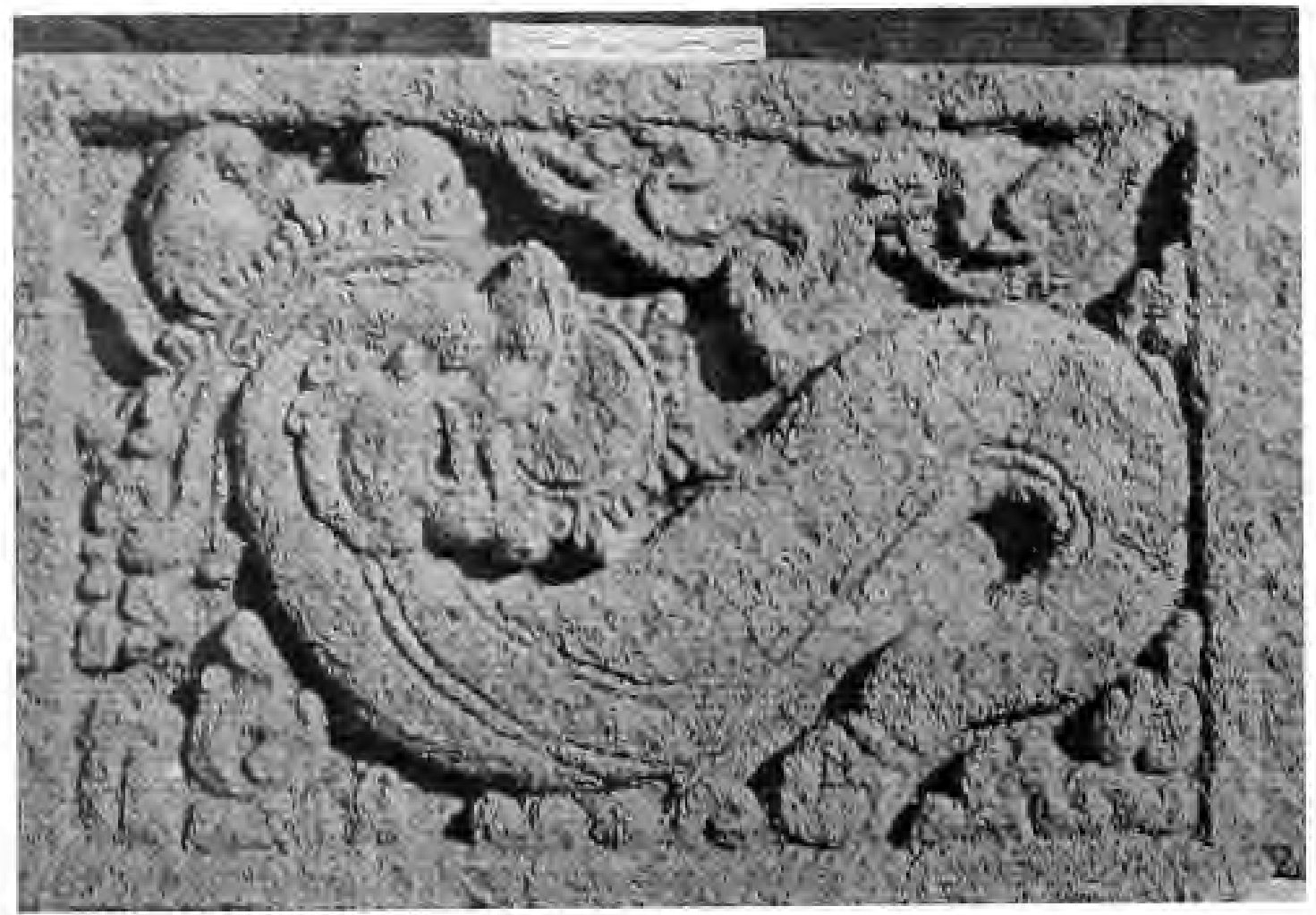

Foto : Panil dengan candrasengkala "Nagaraja anahut Surya" (1318 C atau $1396 \mathrm{M}$ ) 

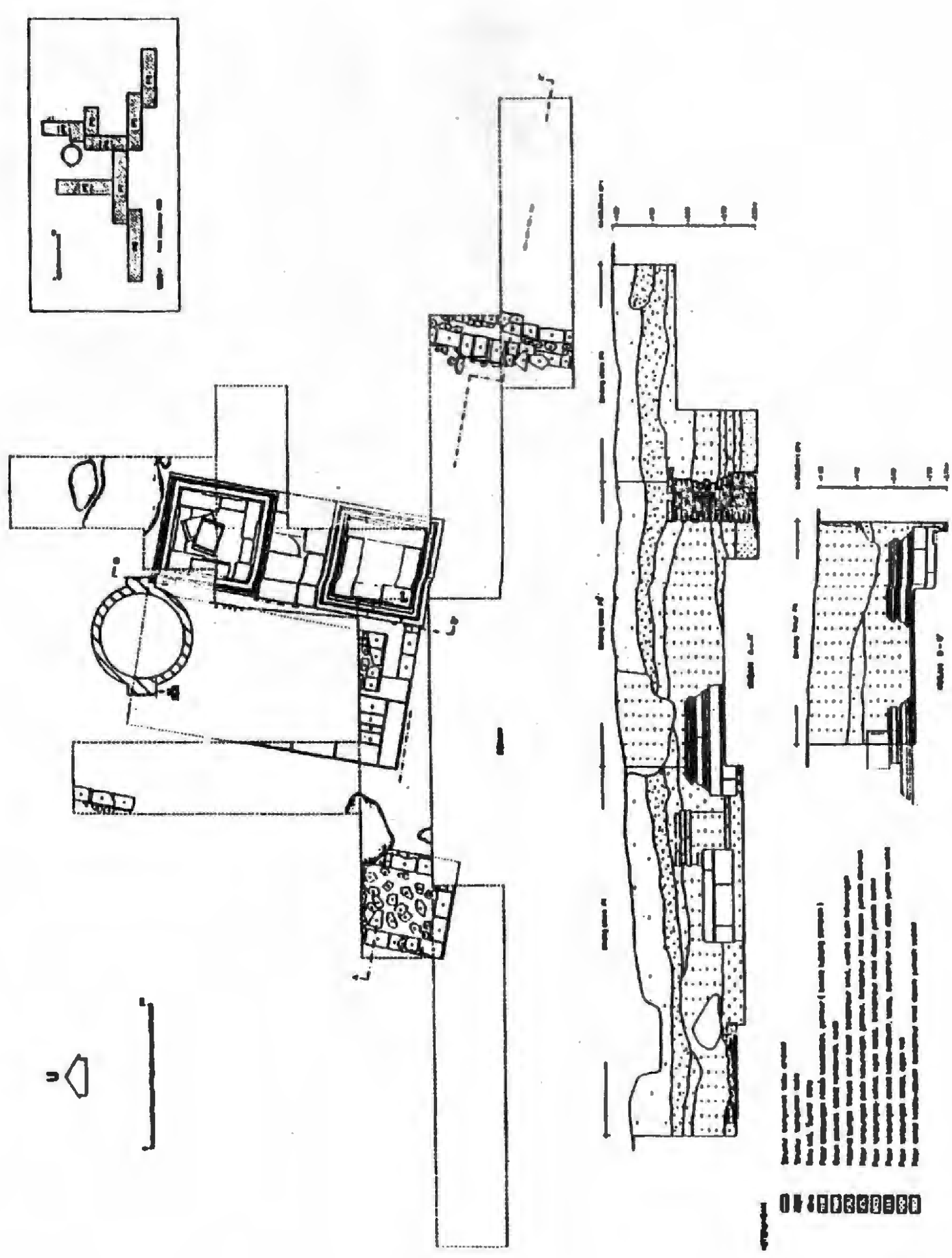

产 